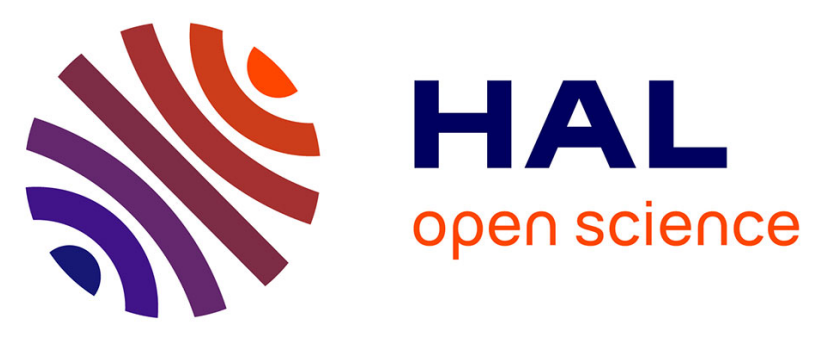

\title{
Undernutrition alters metabolic responses to acute inflammation in early lactation cows
}

\author{
José Pires, Karol Pawlowski, Jacques J. Rouel, Carole Delavaud, Gilles \\ Foucras, Pascal P. Rainard, Pierre Germon, Christine Leroux
}

\section{- To cite this version:}

José Pires, Karol Pawlowski, Jacques J. Rouel, Carole Delavaud, Gilles Foucras, et al.. Undernutrition alters metabolic responses to acute inflammation in early lactation cows. 2016 JAM Joint Annual Meeting, Jul 2016, Salt Lake City, United States. American Society of Animal Science / American Dairy Science Association, 2016, 2016 JAM, Joint Annual Meeting, "Animal and Science: Big Solutions for Grand Challenges". hal-02739016

\section{HAL Id: hal-02739016 https://hal.inrae.fr/hal-02739016}

Submitted on 2 Jun 2020

HAL is a multi-disciplinary open access archive for the deposit and dissemination of scientific research documents, whether they are published or not. The documents may come from teaching and research institutions in France or abroad, or from public or private research centers.
L'archive ouverte pluridisciplinaire HAL, est destinée au dépôt et à la diffusion de documents scientifiques de niveau recherche, publiés ou non, émanant des établissements d'enseignement et de recherche français ou étrangers, des laboratoires publics ou privés. 


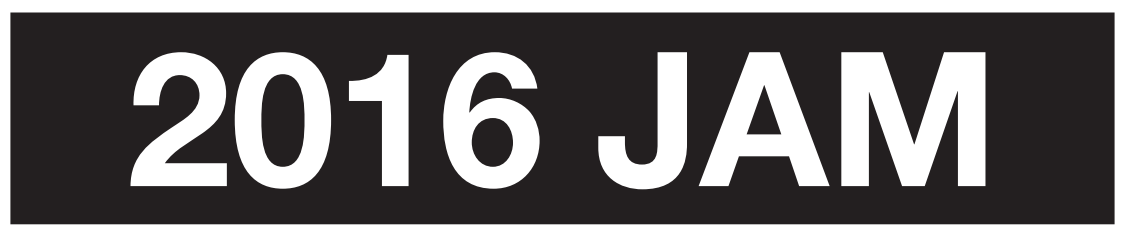

\title{
Joint Annual Meeting
}

\author{
July 19-23, 2016 \\ Salt Lake City, UT
}

American Society of Animal Science Journal of Animal Science Volume 94, E-Supplement 5

American Dairy Science Association ${ }^{\circledR}$ Journal of Dairy Science ${ }^{\circledR}$ Volume 99, E-Supplement 1 
after calving as well as on persistency. Mucus score and DA had a negative impact on milk yield immediately after calving. Consistent with Wood's estimates, Wilmink's estimates indicated that multiparous cows have higher milk production and lower persistency than primiparous cows. Number of mastitis cases and DA were associated with lower overall milk production and higher persistency. Beta hydroxybutyrate was associated with a higher level of milk yield and lower persistency. The ratio of sire to residual variance estimates from Wood's and Wilmink's functions were consistent and approximately 0.4. Wood's model offered a better fit for the lactation curves considered. Our findings demonstrate the need to incorporate disease indicators on the assessment of the genetic component influencing the trajectory of the lactation curve. These findings contribute to a long-term multistate project database (USDA-NIFA-AFRI-003542) for direct measures of fertility.

Key Words: lactation curves, metritis,

nonlinear mixed models

\section{Genetic and environmental components of disease} traits in dairy cattle. T. M. Goncalves ${ }^{* 1}$, D. Gonzalez-Pena ${ }^{2}$, H. Jeong ${ }^{1}$, P. J. Pinedo ${ }^{3}$, J. E. P. Santos ${ }^{4}$, G. M. Schuenemann ${ }^{5}$, G. J. M. Rosa ${ }^{6}$, R. O. Gilbert ${ }^{7}$, R. C. Bicalho ${ }^{7}$, R. Chebel $^{4}$, K. N. Galvão ${ }^{8}$, C. M. Seabury ${ }^{9}$, W. W. Thatcher ${ }^{10}$, and S. L. Rodriguez Zas ${ }^{1},{ }^{1}$ University of Illinois, Champaign-Urbana, ${ }^{2}$ Zoetis, Kalamazoo, MI, ${ }^{3}$ Colorado State University, Fort Collins, ${ }^{4}$ University of Florida, Gainesville, ${ }^{5}$ Department of Veterinary Preventive Medicine, The Ohio State University, Columbus, ${ }^{6}$ University of Wisconsin-Madison, Madison, ${ }^{7}$ Cornell University, Ithaca, NY, ${ }^{8}$ Department of Large Animal Clinical Sciences; University of Florida, Gainesville, ${ }^{9}$ Texas A\&M University, College Station, ${ }^{10}$ Department of Animal Sciences, University of Florida, Gainesville.

Diseases in U.S. Holstein are responsible for losses of approximately $\$ 1$ billion annually in dairy production due to reduced milk production and increased costs. The objective was to assess the impact of environmental factors and magnitude of genetic parameters on the incidence of diseases in dairy cows early $(<10 \mathrm{~d})$ and late $(35$ to $60 \mathrm{~d})$ postpartum. Binary and multinomial disease records on approximately 6000 Holstein cows from farms in Texas, Minnesota, California, and Florida were evaluated using mixed effects logistic and Poisson models. Early postpartum binary diseases included: dystocia, retained placenta, subclinical ketosis (blood $\beta$-hydroxybutyrate BHBA > 1), and metritis. Late postpartum binary diseases included: displacement of abomasum, mastitis, respiratory problems, and clinical endometritis. Mucus score at $7 \mathrm{~d}$, number of mastitis cases up to $60 \mathrm{~d}$, and lameness at $35 \mathrm{~d}$ (five levels) were analyzed assuming a Poisson model. Fixed effects in all models included: lactation number (3 levels), season (summer and winter), U.S. region, and farm. Other fixed effects evaluated depending on the disease included: twins, body condition score, BHBA level, calf gender, stillbirth, first test-day milk production record, and other diseases. The cow's sire was included as a random effect in the models. Overall lactation, region, and season had a significant effect on the incidence of all diseases, except for lactation on respiratory problems, and season on mastitis and displacement of abomasum. First lactation cows exhibited the highest incidence of dystocia, metritis, and clinical endometritis and lowest incidence of mastitis, retained placenta, lameness, and displacement of abomasum. Clinical endometritis, metritis, lameness, and respiratory problems were lower in summer than winter. Dystocia, retained placenta, and subclinical ketosis were positively and significantly associated with clinical endometritis and metritis. Subclinical ketosis and dystocia were positively and significantly associated with displacement of abomasum. Mastitis was negatively and significantly associated with milk yield at first test-day. Heritability estimates for the diseases ranged from 0.06 (retained placenta) to 0.4 (respiratory problems). The differences in genetic parameter estimates among alternative disease descriptors offer insights into effective approaches to lower the incidence of disease through genetic selection. These findings contribute to a long-term multistate project database (USDA-NIFA-AFRI-003542) for direct measures of fertility.

Key Words: metritis, postpartum, production

0141 Undernutrition alters metabolic responses to acute inflammation in early lactation cows.

J. A. A. Pires ${ }^{*}{ }^{1}$, K. Pawlowski ${ }^{1}$, J. Rouel ${ }^{1}$, C. Delavaud ${ }^{1}$, G. Foucras ${ }^{2}$, P. Rainard ${ }^{3}$, P. Germon ${ }^{3}$, and C. Leroux ${ }^{1} .{ }^{1} U M R 1213$ Herbivores, INRA, VetAgroSup, Saint-Genes-Champanelle, France, ${ }^{2}$ UMR1225 IHAP, INRA, Toulouse, France, ${ }^{3} U M R 1282$ ISP, INRA, Nouzilly, France.

The objective was to test effects of nutrient restriction on responses to an intramammary lipopolysaccharide (LPS) challenge in early lactation cows. Multiparous Holstein cows were either allowed ad libitum intake of a lactation diet throughout the study (CON, $n=9,7.1 \mathrm{MJ} / \mathrm{kg} \mathrm{DM} \mathrm{NE}, 17.4 \% \mathrm{CP})$, or the ration was diluted with barley straw (48\% DM) for $4 \mathrm{~d}$ (RES, $n=8,5.2 \mathrm{MJ} / \mathrm{kg} \mathrm{DM} \mathrm{NE}$, $12.2 \% \mathrm{CP}$ ) starting at $24 \pm 3$ $\mathrm{d}$ in milk. After $72 \mathrm{~h}$, one healthy rear mammary quarter was infused with $50 \mu \mathrm{g}$ of LPS (E. coli 0111:B4). Blood samples were collected at $-1.5,-0.5,1,2,4,6$, and $10 \mathrm{~h}$ relative to LPS. Data were analyzed using SAS mixed models. Intake, milk, and protein yields and $\mathrm{NE}_{\mathrm{L}}$ balance did not differ before diet change $(21.8,39.0,1.15 \mathrm{~kg} / \mathrm{d}$, and $-5.6 \mathrm{MJ} / \mathrm{d}$, respectively, on $\mathrm{d}-1)$, but were significantly affected in RES (9.8, $28.3,0.79 \mathrm{~kg} / \mathrm{d}$ and $-74 \mathrm{MJ} / \mathrm{d}$, respectively, on $\mathrm{d} 3$ of restriction and before LPS), as were plasma indicators (Table 1). Insulin response (area under the curve, AUC) to LPS was lower 
Table 0141.

Table 1. Plasma insulin and metabolite concentration at $72 \mathrm{~h}$ of dietary treatments and response to LPS challenge. $P<0.01$ for all variables.

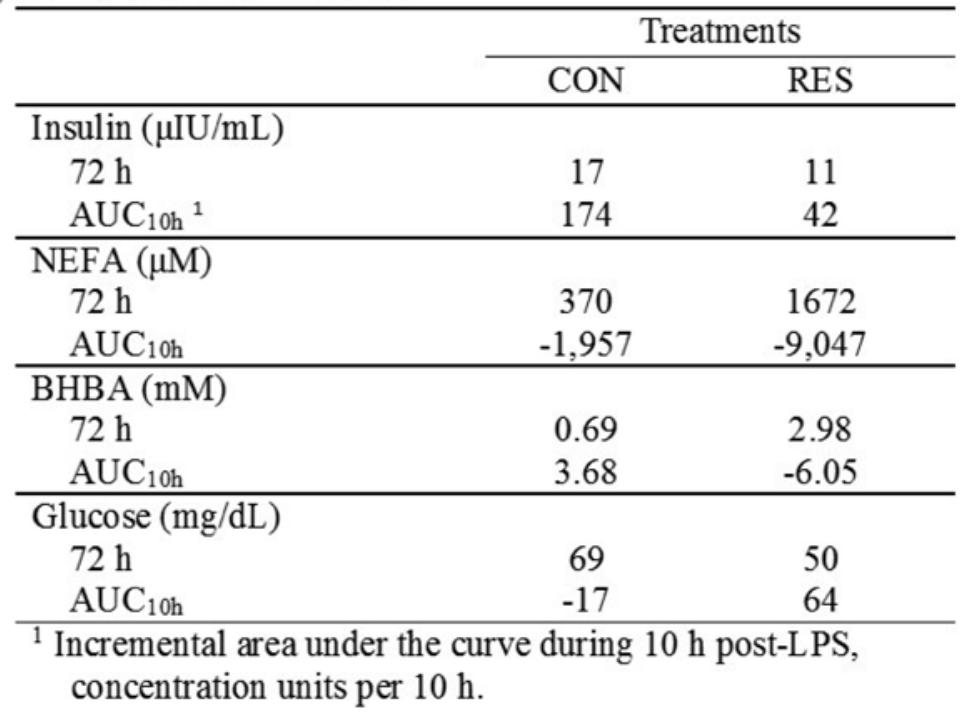

in RES compared with CON, but it was greater for NEFA, BHBA, and glucose. The NEFA nadir post LPS was 599 and $101 \mu \mathrm{M}$ at $4 \mathrm{~h}$ for RES and CON $(P \leq 0.001)$, respectively, and it preceded insulin change in RES. The BHBA decrease in RES was consistent with NEFA response to LPS, but BHBA increased from a low baseline in CON (treatment $\times$ time interactions, $P \leq 0.05$ ). The negative glucose AUC in CON could be related to the insulin increase post LPS. Rectal temperature increase did not differ between treatments $\left(+2.1 \pm 0.15^{\circ} \mathrm{C}\right.$ at 6 h). Nutrient restriction altered peripheral metabolic responses to an intramammary LPS challenge.

Key Words: inflammation, undernutrition, dairy cow

\section{Potential modulation of the toxic effects of Escherichia coli in bovine endometrium by lactic acid bacteria. S. Genís ${ }^{* 1}$, A. Sánchez-Chardi ${ }^{2}$, A. Bach ${ }^{3,4}$, and A. Arís ${ }^{1}{ }^{1}$ Department of Ruminant Production, IRTA, Caldes de Montbui, Spain, ${ }^{2}$ Servei de Microscopia, UAB, Cerdanyola del Valles, Spain, ${ }^{3}$ ICREA, Barcelona, Spain, ${ }^{4}$ IRTA, Caldes de Montbui, Spain.}

The ultrastructural assessment of toxic effects using field emission scanning electron microscopy (FESEM) and transmission electron microscopy (TEM) can provide important information to elucidate the mechanisms of infection and to develop preventive strategies. The aim of this study was to evaluate the effects of a lactic acid bacteria (LAB) combination, based on L. rhamnosus MOI 25, P. acidilactici MOI 25, and $L$. reuteri MOI 2, at preventing Escherichia coli infection and maintaining bovine endometrial tissue health. Triplicate samples of epithelial cell cultures were studied in a $2 \times 2$ factorial design in the presence or absence of an $E$. coli infection and with or without LAB. Samples were mounted in FESEM stubs and observed without coating in a Zeiss Merlin microscope. A qualitative assessment of general structure of the epithelium (size and shape of cells, ultrastructure, and amounts of ultrastructure of microvilli), presence of $E$. coli and LAB in cell surface, cell debris, presence of mucus in the cell surface, mitochondrial damage, and cell death was performed by the analysis of 10 random selected areas for each treatment. For TEM, contrasted ultrathin sections were observed in a Jeol 1400 operating at $80 \mathrm{kV}$. A semiquantitative approach was performed by the analysis of 10 random selected sections in three areas for each treatment and data were analyzed using a Fisher exact test. Escherichia coli alone or with LAB appeared in low numbers in epithelial cells surface and in no case formed biofilms or interactions between each other. Escherichia coli abundance was lower $(P<0.05)$ in samples treated with LAB than in those infected with $E$. coli alone. Healthy epithelium was observed in cells treated with LAB (epithelial cells with normal size and shape and normal aspect of microvilli), whereas in cultures infected with $E$. coli, abundant areas with cell debris and bacilli in epithelial cell surface were observed. The incidence of necrosis (as assessed by TEM) in E. coli samples tended $(P=0.07)$ to be greater than in noninfected cultures. Control or LAB preincubated cells showed less mitochondrial damage $(P=0.01)$ than nontreated cells, a parameter strongly related to cell death. Overall, LAB appear to offer protection against $E$. coli, by mechanism different than the formation of biofilms, and thus, LAB combinations could be used as a preventive strategy for metritis.

Key Words: endometrium, FESEM, TEM 